\title{
Some New Epigraphy Material from the Hashemite Kingdom of the Jordan
}

\author{
Ali Al-Manaser ${ }^{1} \&$ Hind Mohammad Turki Al Turki ${ }^{2}$ \\ ${ }^{1}$ The Ministry of Tourism and Antiquities, Jordan \\ ${ }^{2}$ Princess Nourah bint Abdulrahman University, Kingdom of Saudi Arabia \\ Correspondence: Ali Al-Manaser. E-mail: manaser_ali@hotmail.com
}

Received: July 7, $2020 \quad$ Accepted: July 16, $2020 \quad$ Online Published: July 31, 2020

doi:10.5539/ass.v16n8p102 URL: https://doi.org/10.5539/ass.v16n8p102

\begin{abstract}
The aim of this research is to present a new collection of $A N A$ inscriptions (Safaitic) discovered in 2017 in the Jordanian northeastern Badia in the area of Tall Al-Hafit. The research attempts to add a new meaning to the interpretation of the verb ' $w r$ in the Safaitic inscriptions. This research also introduces a new inscription bearing a reference to the town of Salkhad, which is located in southern Syria. This is the fifth inscription mentioning the name of this town. In addition, the research attempts to shed light on the importance of interpreting Safaitic inscriptions in relation to their geographical locations (the places where the inscriptions were discovered). This is because it is believed that these inscriptions and the meanings their authors wanted to convey can be better understood when interpreting these inscriptions in relation to their geographical contexts.
\end{abstract}

Keywords: pre-Islamic Arabian language, Ancient North Arabian, Safaitic inscriptions, Badia Epigraphic Survey

\section{Introduction}

The inscriptions of the present study were found during the surveys conducted by the research team of Badia Epigraphic Survey $(B E S)$ in 2017 in the north-eastern Badia of Jordan in the area of al-Hafit, which has slightly more altitude than the surrounding areas. In al-Hafit area, there is Tall al-Hafit and the area of Mrabb al-Hafit, which is geographically connected to the area of the Wādī al-Khuḍarī and Wādī Hashād al-Khuḍarī. During this survey, 2,303 Safaitic inscriptions were found, and they are planned to be published in the OCIANA database (The Online Corpus of the Inscriptions of Ancient North Arabia) (http://krcfm.orient.ox.ac.uk/fmi/webd/ociana). Since 2015, regular surveys, as a part of Ociana Project (Badia Epigraphic Survey, BES), have been conducted to document the inscriptions in the north-eastern Badia of Jordan through the use of the Global Positioning System (GPS). Five surveys have so far been carried out in the period between 2015 and 2020, and these surveys led to the discovery of a collection of approximately 10,000 Safaitic, Nabataean, Palmyrene, Greek, Islamic, mediaeval and modern Arabic inscriptions. In addition to the afore-mentioned goal, the Ociana Project aims to encourage researchers from all over the world to pay attention to such inscriptions. It also aims at highlighting the importance of interpreting the contents of the inscriptions in relation to the place where they were found. This is because it has been noticed that many of the verbs used in the inscriptions are closely related to the place where these inscriptions were found. For example, the verb, nzr is often used in inscriptions found in highlands that are overlooking valleys. In addition, the phrases, $w$ wgd 't $r$ (and he found the inscription), and, $w$ bny $h$-rgm (and built this cairn), are sometimes found in inscriptions engraved on the stones of tombs or cairns; and it is believed that the author of these inscriptions is attempting to communicate to whoever will find these inscriptions that he has found or built this landmark. Furthermore, the surveys have shown that the highest density of rock art is located near Abar Al-Ghusyn and Abar al-Khuḍarī. Besides, the results of the surveys indicated the existence of many Nabataean and Greek inscriptions in the areas near Wādī al-Khuḍarī towards Qasr Burqu'. Moreover, many Greek and Safaitic inscriptions of important contents were found near the road extending from Qasr Burqu' to southern Syria and crossing through Wādī al-Khuḍarī, Tall al-Hafìt, Wādī Salma, Wādī Hashād and Wādī Sarah. Furthermore, near this road many Islamic-Arabic inscriptions dated to the second century AH, especially during the reign of Caliph Hisham ibn Abd al-Malik, were found. However, the surveys also demonstrated that important inscriptions are not exclusively found around valleys and in cairns but also in distant areas. These inscriptions are occasionally distinguished by the use of the verb, qnt (he was afraid), 
indicating that the author of the inscription had escaped and hid away from the main road or the exposed valleys ${ }^{1}$

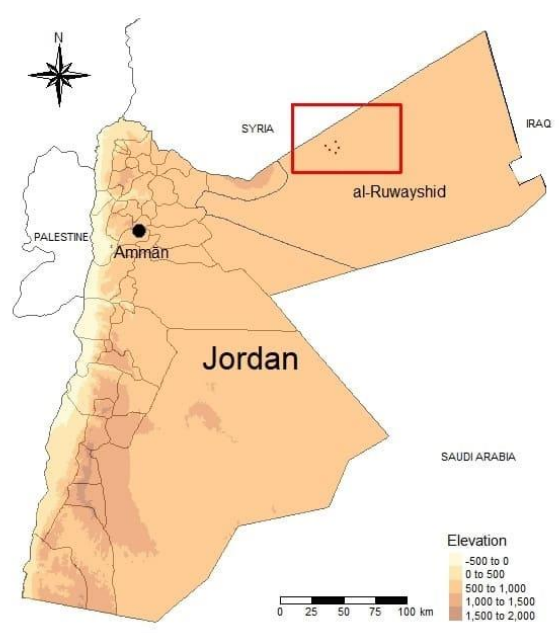

Figure 1. A map showing the sites on which the inscriptions were recorded (Map: Orhan Elmaz)

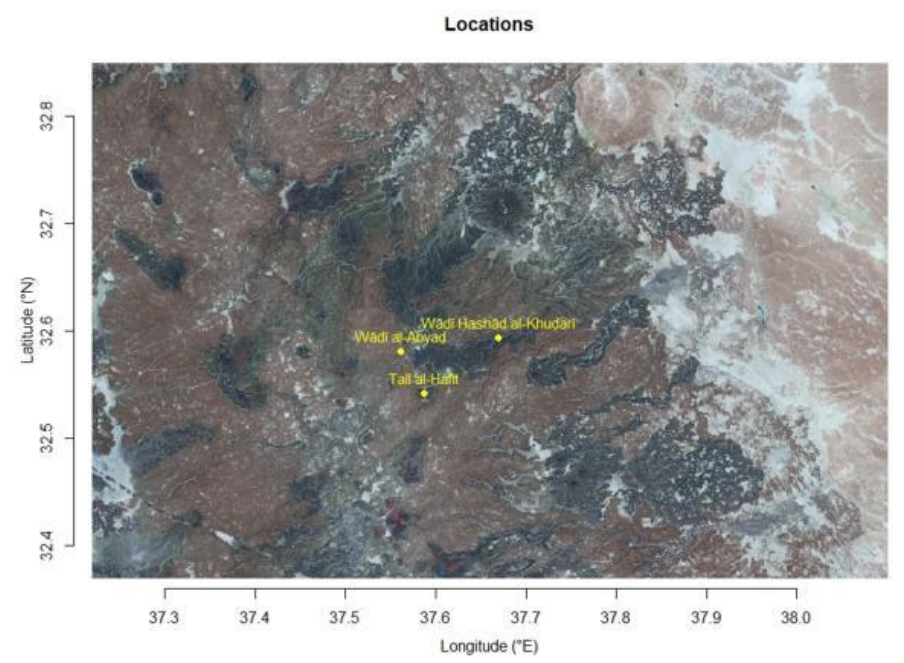

Figure 2. Map of Jordan showing the location of Tall al-Hafit area (Map: Orhan Elmaz)

\section{The inscriptions}

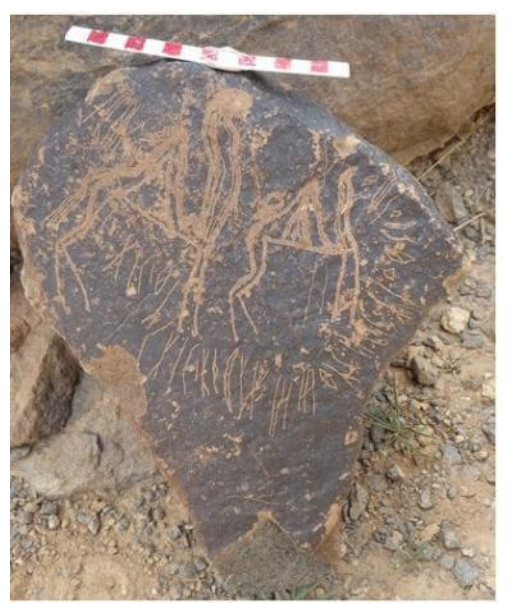

Figure 3. Stone 1 (Photograph: A. Al-Manaser).

\footnotetext{
${ }^{1}$ These inscriptions were interpreted and discussed in collaboration with Michael C. A. Macdonald, the co-director of the Badia Epigraphic Survey (BES) projects from 2015 to 2020.
} 


\section{BES_TH_1}

\section{Transliteration}

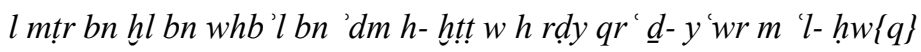

\section{Translation}

By Mțr son of Hl son of Whb'l son of ' $\mathrm{dm}$ is the carving and O Rḍy inflict baldness/ harm whoever scratches out what is on the stone

\section{Commentary}

The basalt stone, on which this inscription was engraved, has been subject to some fracture as shown in the picture of this stone. The inscription is carved round drawings of a male and female camel apparently with rich trappings. It appears that the drawing of the she-camel and the male camel had been made before the inscription was engraved as the letters of the inscription are encircling the drawing. All the letters of the inscription are clear and easy to read apart from the last two letters. However, it has been possible to figure out these two letters by comparison with the other similar inscriptions. After stating his genealogy, the author mentioned that the beautiful drawing of the camel on the stone, then he requested from the deity Rdy to inflict baldness on whoever scratches out the inscription. For $q r$ ' we have compared Arabic qara' $u$ ar-Rāsi which is known to translate to "to completely lose hair on the head". It is also defined in some sources as "to lose hair as a result of a disease" (Ibn Manzūr 3594). The last word in the inscription can be compared to inscription AMSI 131 and, thus, can be translated to mean 'stone'.

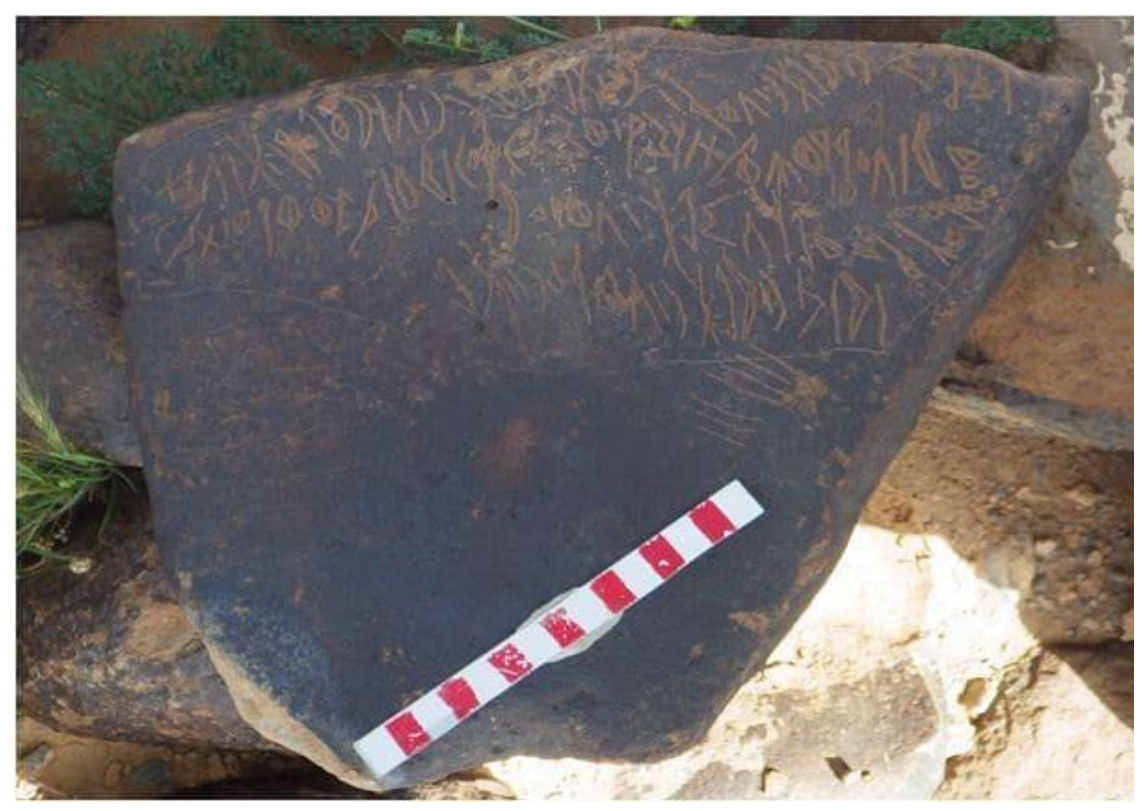

Figure 4. Stone 2 (Photograph: A. Al-Manaser).

\section{BES_TH_2}

\section{Transliteration}

l ġtnf bn $m r^{\prime}$ bn $s^{l} w d n$ bn $n h r\{b\}\{n\}\{\dot{g}\}\{r\} b$ bn $s^{l} l m w r^{\prime} y h$ - nhl slnt 'bdt nwy w wrd l- gml b- 'qbt $f$ wny fh lt $r w h w y \underline{t}^{\prime} s^{1} l m w ' w r \underline{d} y{ }^{\prime} w r h-s^{l} f r{ }^{\prime} n s^{1} w n^{\prime} m$

\section{Translation}

By Ġtnf son of Mr' son of $\mathrm{S}^{1} \mathrm{wdn}$ son of $\mathrm{Nhr}\left\{\right.$ son of $\left\{\right.$ Ǵrb\} son of $\mathrm{S}^{1} \mathrm{~lm}$ and he pastured this valley the year of 'bdt he migrated and came to water in Scorpio and then he became feeble and so O Lt grant relief and $\mathrm{Yt}_{\mathrm{t}}$ [grant] security and blind/ harm whoever, whether man or beast, scratches out the inscription.

\section{Commentary}

This inscription was engraved on a basalt stone in a spiral pattern. The author framed the inscription with a line in a circular form and engraved seven lines that are commonly believed by researchers to be a form of sorcery for the sake of protection of the inscription (Al-Manaser 2008: 51). It seems that the author had drawn the framing line before engraving the script; this is inferred from the limited space available for the letters of the 
inscription within the frame. There is also another inscription below this one. The author dated his inscription to the year of ' $b d t$ who could have been a famous person or a regular person but relevant to the author. In this regard, there is another Safaitic inscription dated to reign of Nabataean king Obadat (ANKS 1). The author also requested from (prayed for) the deity Lt to grant security and safety, and requested from the deity $Y \underline{t}{ }^{\prime}$ to grant peace and inflect harm on whoever scratches out the inscription whether being a human or a herd animal. It is noteworthy to mention that the phrase ' $n s^{1} w n ' m$ was mentioned in another Safaitic inscription (KRS 1179). It is also possible that this phrase refers to personal names as it is difficult to interpret $n$ ' $m$ as a herd of animals.

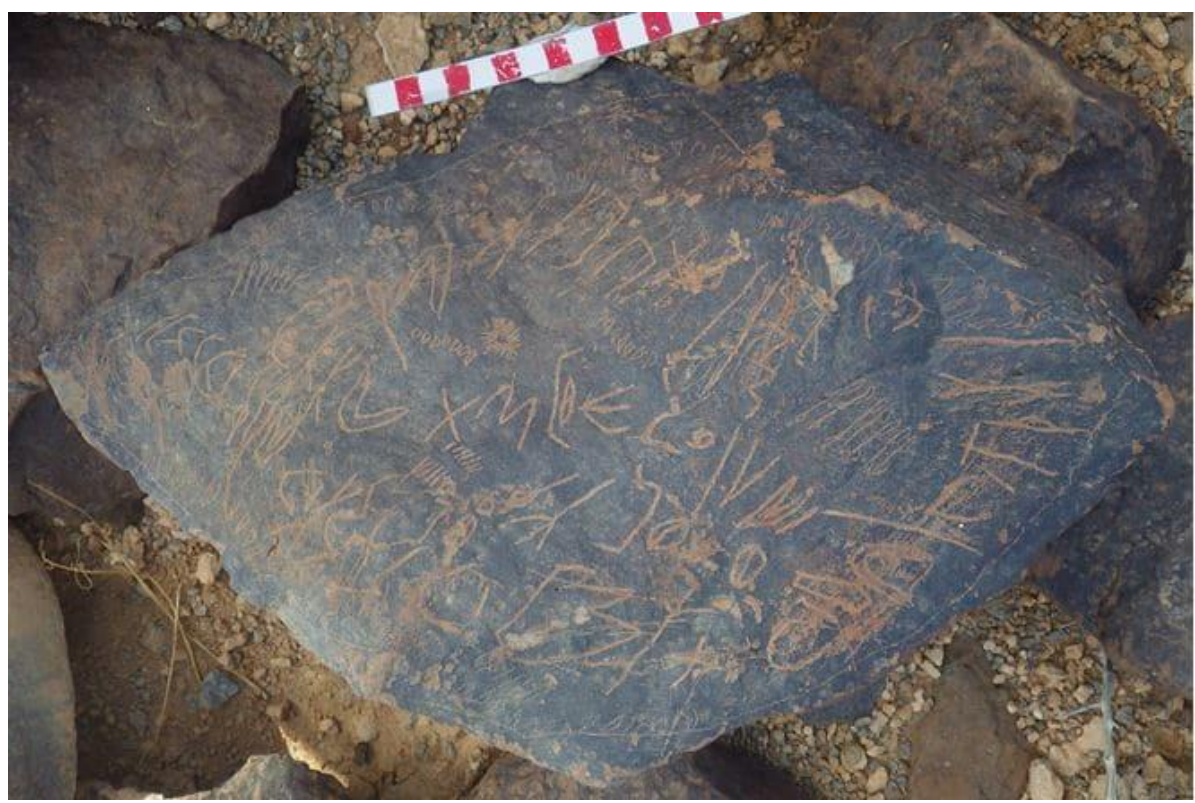

Figure 5. Stone 3 (Photograph: A. Al-Manaser).

\section{BES_TH_3}

\section{Transliteration}

l rkb bn qs'm bn 'ftn bn r'ft bn gml bn zd'l bn 's'll w tzr h- slmy b- r' 'mtfrwh b'l s'mn w'wr $\underline{d} y^{\prime} w r$

\section{Translation}

By son of $\mathrm{Qs}^{1} \mathrm{~m}$ son of ' $\mathrm{ftn}$ son of $\mathrm{Gml}$ son of $\mathrm{Zd}$ '1 son of 's $\mathrm{s}^{2} 11$ and he waited for the rains at the rising of Libra and so relief $\mathrm{B}^{1} 1 \mathrm{~s}^{1} \mathrm{mn}$ and blind/ harm whoever scratches out [the inscription]

\section{Commentary}

This inscription was engraved on a basalt stone and some of it letters were vandalized but it can be read completely. The stone also shows various engravings such as seven dots, circles and seven lines. The inscription is surrounded by a circular frame; possibly for the sake of protection of the handwriting. This inscription is Safaitic and it was a common practice among Safaitic authors to encircle their inscriptions with various kinds of frames (RSIS 17; CSI.S 12). It appears that the author of the inscription long waited for the rain and he requested from the deity $B^{\prime} l s^{l} m n$ for relief from drought (KRS 1988; ASWS 185; RWQ 281). At the end of the inscription, the author requested from the deity to harm whoever harms or scratches out the inscription. There are many examples in the Safaitic inscriptions indicating the main function of the various deities. For example, $B^{\prime} l s^{l} m n$ is commonly referred to by the authors when they seek relief from drought ${ }^{2}$.

\footnotetext{
${ }^{2}$ For ' $m t$ as Libra see Al-Jallad 2014: 218, 220; 2016: 101-102.
} 


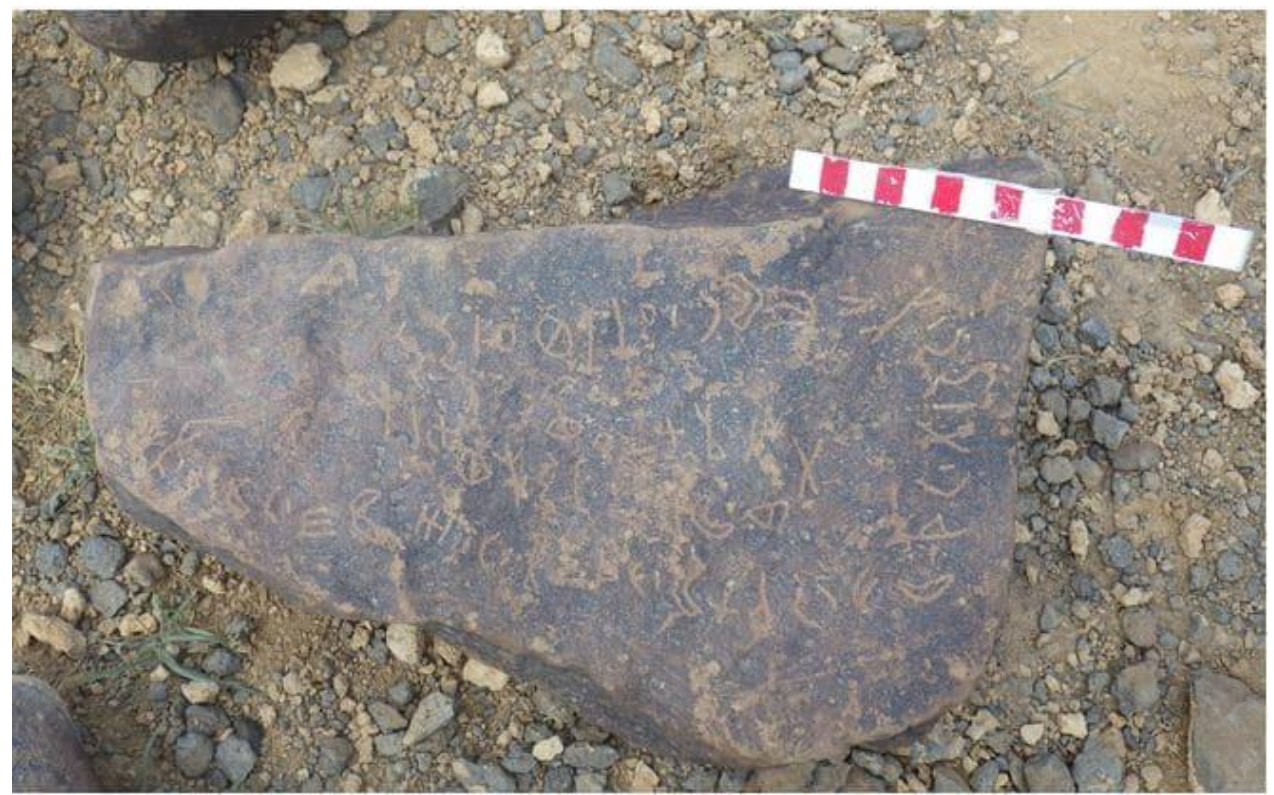

Figure 6. Stone 4 (Photograph: A. Al-Manaser).

\section{BES_TH_4}

\section{Transliteration}

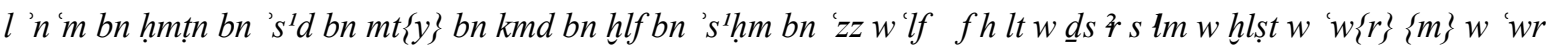

\section{Translation}

By ' $n$ ' $m$ son of Hmtn son of 's'd son of $\{$ Mty\} son of Kmd son of Hlf son of 's'hm son of 'zz and he fed [the animals] on dry fodder and so O Lt and Ds² [grant] security and safety and \{blind $\} /$ harm whoever scratches out [the inscription]

\section{Commentary}

This inscription was engraved on a basalt stone, and it is clear that many of its letters have been damaged. This is likely because the stone was transferred from its original location to be used in a cairn; where it was positioned face-down. The transliteration of this inscription was based those letters which have been preserved, and our familiarity with the Safaitic words and the commonly used phrases. It appears that the author of this inscription fed [his animals] on dry fodder. It is worth notingthat the author did not specify what types of animals he possessed. It could have been sheep, goats, or camels....etc. It is a common for the authors ofthe Safaitic inscriptions not to specify the type of animals when using the verb « $l f$ « to feed on dry fodder» on dry fodder (C 3933; SIT 12; AbHYN 1; AAEK 67). The author also asked the deities Lt and Ds² to grant him security and safety and to harm whoever scratches out the inscription.

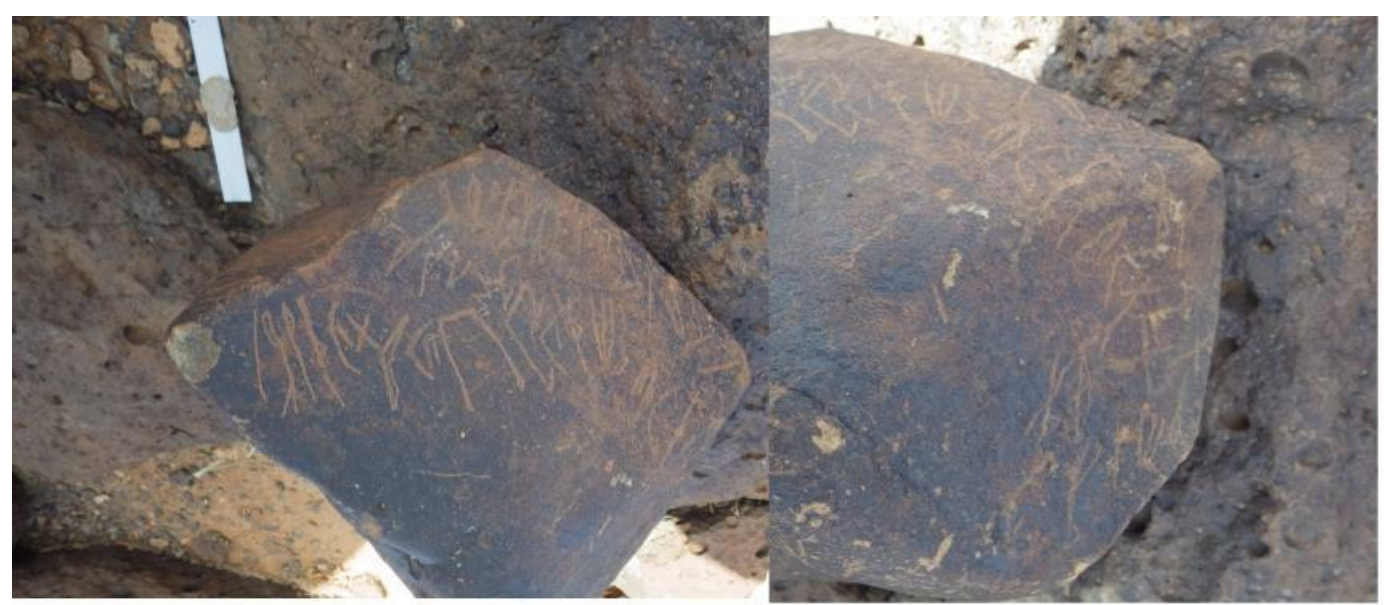

Figure 7. Stone 5 (Photograph: A. Al-Manaser). 


\section{BES_TH_5}

\section{Transliteration}

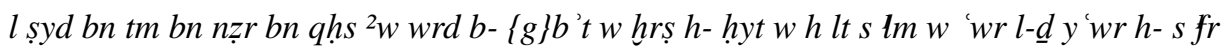

\section{Translation}

By Syd son of Tm son of Nzr son of Qhs ${ }^{2}$ and he went to water at cavities where water collects and he was watching for the abundant rains and $\mathrm{O}$ Lt [grant] security and [inflict] blindness/ harm on whoever scratches out this inscription.

\section{Commentary}

This inscription was engraved on multiple sides of a basalt stone. All the letters are well-preserved and can be easily read. On one of its sides, there is a drawing of a female camel. It appears that the author went to the $g b^{\prime} t$ area with his herd, and he waited there for abundant rain to come. The word $g b^{\prime} t$ is commonly used by the inhabitants of the Jordan Badia to refer to a rocky area with cavities where water collects. The word $g b^{\prime} t$ could be compared with Arabic ğiba' $a h$ the plural of ğab' «a hollow or cavity in a mountain where water of the rain stagnates or collects» (Lane 372c). The Badia Epigraphic Survey team noticed, during the field surveys, that the areas close the $g b^{\prime} t$ area are generally characterized by an abundance of rock art drawings and Islamic-Arabic inscriptions, in addition to the presence of some Islamic mosques (Al-Manaser and Ellis 2018: 72). This is likely due to the stagnation of water in these areas for at least three months, and thus they are more attractive for longer residence for the Bedouins than the dry areas in the desert. By the end of the inscription, the author requested from Lt to grant security and inflict harm on whoever scratches out this inscription ${ }^{3}$.

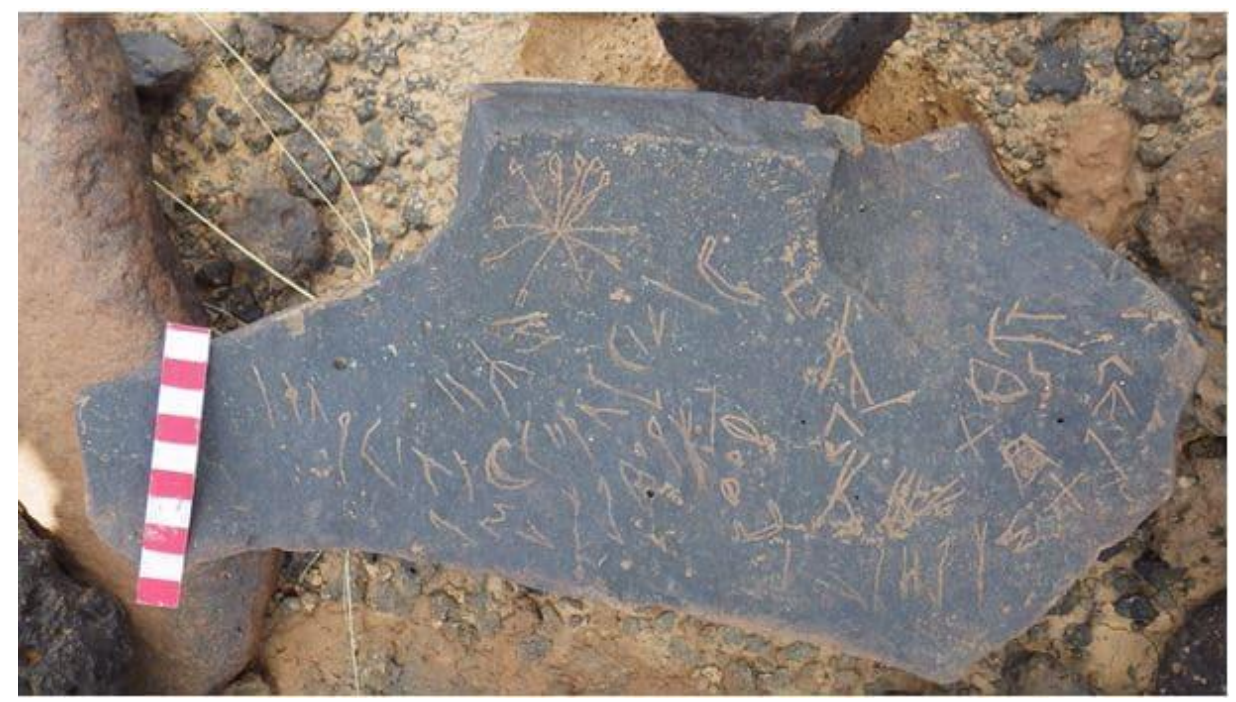

Figure 8. Stone 6 (Photograph: A. Al-Manaser).

\section{BES_TH_6}

\section{Transliteration}

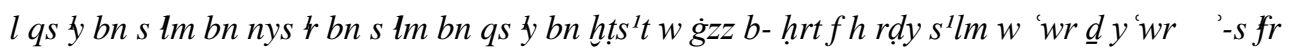

\section{Translation}

By Qs $s^{1} y$ son of $S^{1} \operatorname{lm}$ son of Nys ${ }^{1} r$ son of $S^{1} l m$ son of $Q^{1} y$ son of Hțs ${ }^{1} t$ and he raided in the harrah and so O Rḍy [grant] security and blind/ harm whoever scratches out the inscription

\section{Commentary}

This inscription was engraved on a basalt stone using thin letters. The inscription was also accompanied by a circular drawing implementing the Safaitic letter $y$. This kind of drawing is frequently used in Safaitic inscriptions. The inscription reveals revealed that the author raided in the harrah and so he requested from the deity Rḍ to grant security and harm whoever scratches out the inscription. It is noteworthy to mention that the author used the letter ' as a definite article instead of the commonly used $h$ - letter (see LP 150).

\footnotetext{
${ }^{3}$ Michael C.A. Macdonald Comments: "Given the author's situation, $h$-hyt may be the "abundant rains" as explained by Musil (1928 Rwala: 542) but note that in Classical Arabic the word is hayan not hayah (Lane 681c)"
} 


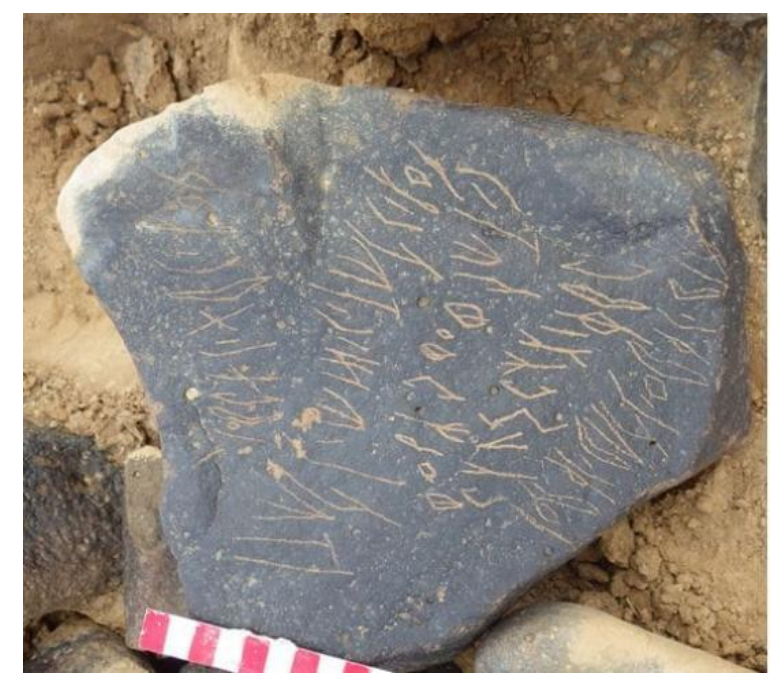

Figure 9. Stone 7 (Photograph: A. Al-Manaser).

\section{BES_TH_7}

\section{Transliteration}

l zhk bn hṭtn bn zhk bn ș'd bn zhkw 'wr $\underline{d} y^{\prime} w r h$ - slfr $\underline{d}$ - 'l qmr

\section{Translation}

By Zḥk son of Ḥṭn son of Zḥk son of Ș'd son of Zḥk and blind/ harm whoever scratches out this "inscription" of the lineage of Qmr

\section{Commentary}

Three Safaitic inscriptions are engraved on this stone, with the longest being the one in the middle. The inscription in the middle showed that the author requested from the deity to harm whoever scratches out this inscription of the lineage of Qmr. The tribe of Qmr is well-known in the Safaitic, with its name being mentioned in more than twenty Safaitic inscriptions (C 8; WH 729; SIJ 840).

\section{BES_TH_8}

\section{Transliteration}

$l$ 'md bn $m s^{1} k$ bn 'md bn $m l k$

\section{Translation}

By ' $m$ d son of $\mathrm{Ms}^{1} \mathrm{k}$ son of ' $\mathrm{md}$ son of Mlk

\section{BES_TH_9}

\section{Transliteration}

l'mrt bn tmbnṣ'd

\section{Translation}

By 'mrt son of Tm son of Ș'd 


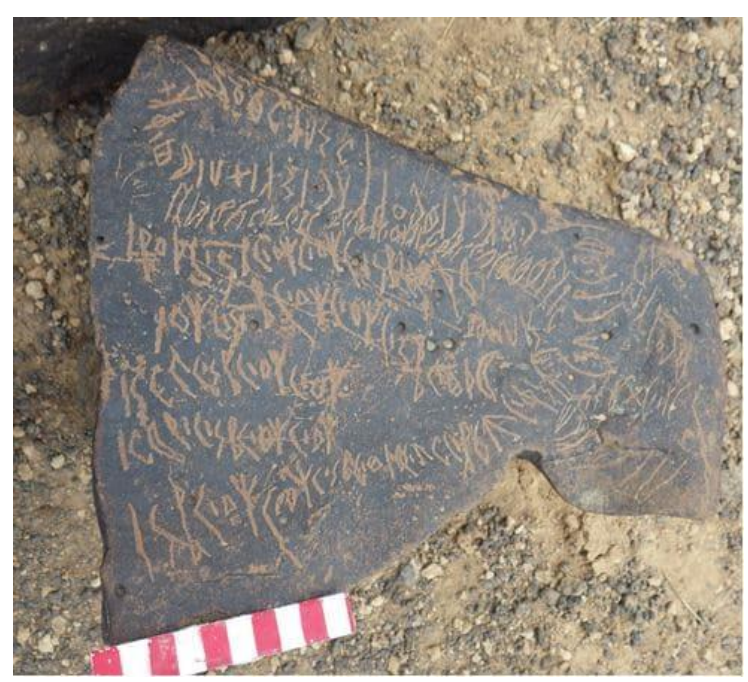

Figure 10. Stone 8 (Photograph: A. Al-Manaser).

\section{BES_TH_10}

\section{Transliteration}

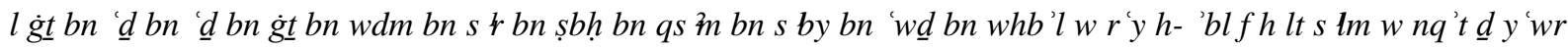
$h-s^{l} f r$

\section{Translation}

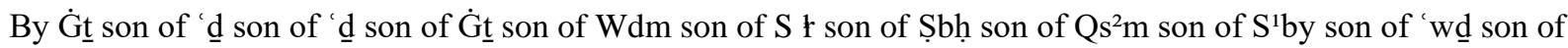
Whb'l and he pastured the camels and so O Lt [grant] security and [inflict] ejection from the grave [on] whoever scratches out the inscription

\section{Commentary}

This stone carries seven Safaitic inscriptions which overlap each other. Meanwhile, the second inscription revealed that the author pastured the horse. It is noteworthy to mention that the stone does not have any drawing of a camel or a horse (see C 4855; LP 573; KRS 234). The third inscription mentioned that the author found the traces of Ǵt and he grieved in pain. In Safaitic inscriptions, the word 't $\underline{t}$, translated as trace, commonly refers to anything related to the person in question which could be an inscription, a construction, or a landmark (see WH 2108; MZS 3). It should be noted that BES_TH_11-14 are by four brothers.

\section{BES_TH_11}

\section{Transliteration}

lź̧n\} bn șbh bn $s^{2} m t$ bn nhb wry h-frs ${ }^{1}$

\section{Translation}

By Z $\{\mathrm{n}\}$ son of Șbh son of $\mathrm{S}^{2} \mathrm{mt}$ son of Nhb and he pastured the horse

\section{BES_TH_12}

\section{Transliteration}

l rmyn bn g $\underline{d} b n$ ' $\underline{d} b n$ ' $\underline{d}$

\section{Translation}

By Rmyn son of Git son of ' $\underline{d}$ son of ' $\underline{d}$

\section{BES_TH_13}

\section{Transliteration}

$l s^{2} r k b n \dot{g} \underline{t} b n \stackrel{d}{d} b n \stackrel{d}{d}$

\section{Translation}

By $S^{2} \mathrm{rk}$ son of $\dot{\mathrm{G}} \underline{\mathrm{t}}$ son of ' $\underline{\mathrm{d}}$ son of ' $\underline{\mathrm{d}}$ 


\section{BES_TH_14}

\section{Transliteration}

$l \underline{d} b n \dot{g} \underline{t} b n$ ' $\underline{d} b n$ ' $\underline{d} b n \dot{g} \underline{t} b n w d m$

\section{Translation}

By ' $\underline{d}$ son of $\dot{G} \underline{t}$ son of ' $\underline{d}$ son of ' $\underline{d}$ son of G $\underline{t}$ son of Wdm

\section{BES_TH_15}

\section{Transliteration}

$l s^{\prime} d b n \dot{g} \underline{t} b n$ 'd $\underline{d} b n$ ' $\underline{d} b n \dot{g} \underline{t} b n w d m$

\section{Translation}

By Ș'd son of Ġt son of ' $\underline{d}$ son of ' $\underline{d}$ son of G $\underline{t}$ son of Wdm

\section{BES_TH_16}

\section{Transliteration}

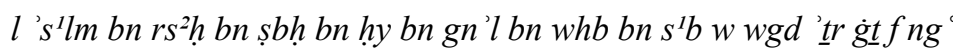

\section{Translation}

By ' ${ }^{1} 1 \mathrm{~lm}$ son of Rsª̣ son of Șbḥ son of Ḥy son of Gn'1 son of Whb son of $\mathrm{S}^{1} \mathrm{~b}$ and he found the traces of G $\underline{t}$ and he grieved in pain

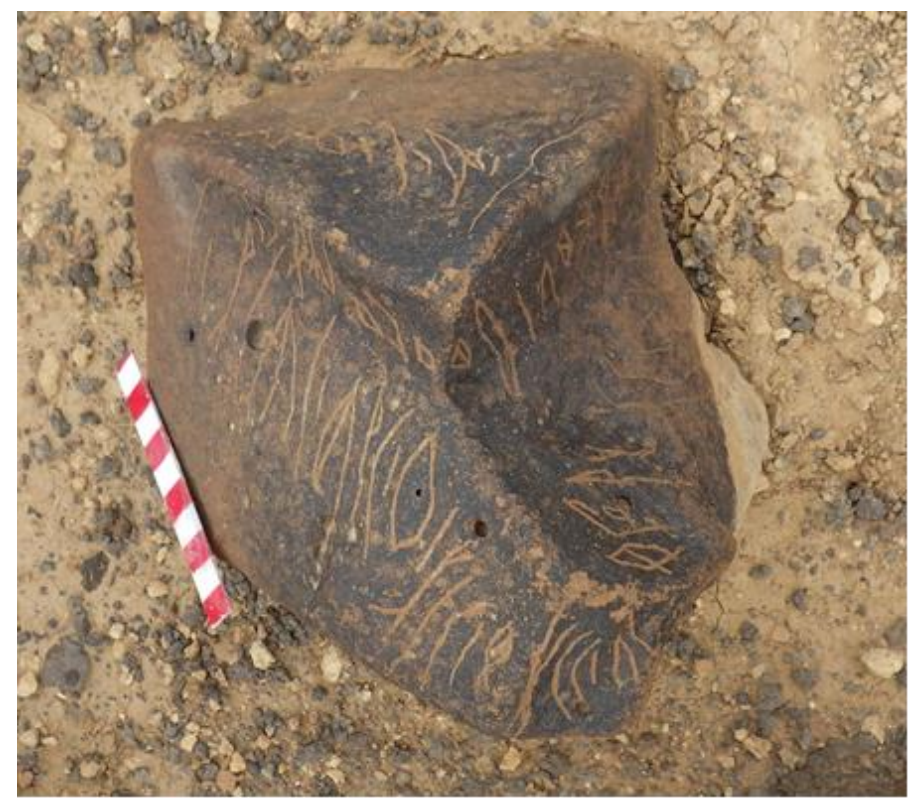

Figure 11. Stone 9 (Photograph: A. Al-Manaser).

\section{BES_TH_17}

\section{Transliteration}

ln 'mn bn gn'l bn hy bn șbh bn gn'l bn whb bn s'rw r'y h- 'blfh lt gnyt w s'lmw 'rg l- $\underline{d}$ hbl

\section{Translation}

By N'mn son of Gn'l son of Hy son of Șbh son of Gn'l son of Whb son of $\mathrm{S}^{1}$ rand he pastured the camels and so O Lt [grant] abundance and security and [inflict] lameness on whoever obscures [it]

\section{Commentary}

This inscription was engraved on the multiple faces of the stone. The corners of this stone are damaged. The inscription shows that the author pastured the camels and requested from the deity Lt to grant abundance and security and to inflict lameness on whoever obscures the inscription. The word ' $r g$, translated as lameness (Lane 1996b), appeared in many Safaitic inscriptions indicating that it was common amongst the authors of Safaitic inscriptions to pray for their deities to inflict physical harm on those who damage their inscriptions (see C 1186; WH 368; SIJ 296; AbSWS 18). 


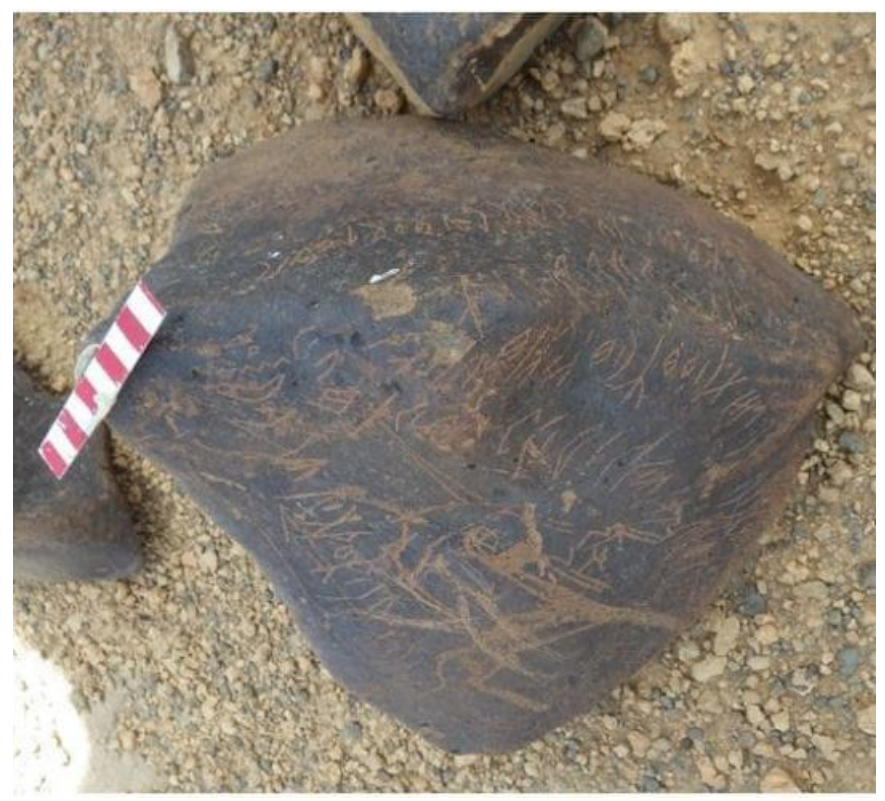

Figure 12. Stone 10 (Photograph: A. Al-Manaser).

\section{BES_TH_18}

\section{Transliteration}

l ș'd bn tm bn ș'd bn zhk bn $m s^{2} r$ bn $s^{l} w d$ bn wtr bn mlk bn hyt bn hbl bn \{w\}hbn bn \{q\}mr bn rth bn 'wd bn

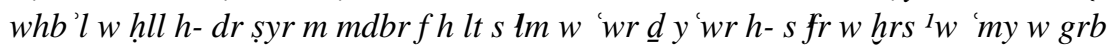

\section{Translation}

By Ș ${ }^{\prime} d$ son of Tm son of $S^{\prime} d$ son of Zḥk son of $\mathrm{Ms}^{2}{ }^{2} r$ son of $S^{1} w d$ son of Wtr son of Mlk son of Hyt son of Hbl son of $\{$ Whbn $\}$ son of $\{\mathrm{QMr}\}$ son of Rth son of 'wd son of Whb'l and he camped here travelling to a watering-place from the inner desert and so O Lt [grant] security and blind/ harm whoever scratches out the inscription and [inflict on him] dumbness, and blindness, and mange.

\section{Commentary}

This inscription was engraved on all sides of the stone. There is also a drawing of a camel accompanying this inscription. The inscription revealed that the author camped there after travelling to a watering-place from the inner desert and so he requested from the deity Lt to grant security and to inflect harm, dumbness, blindness, and mange on whoever scratches out the inscription (see C 2779; WH 368; RSIS 351). For ' $m y$ we have compared Arabic 'aman (mașdar of 'amiya "to be blind in both eyes", Lane 2160c), for grb we have compared Arabic ğarab "mange, scab" or "disease upon the eyelids" (Lane 403a).

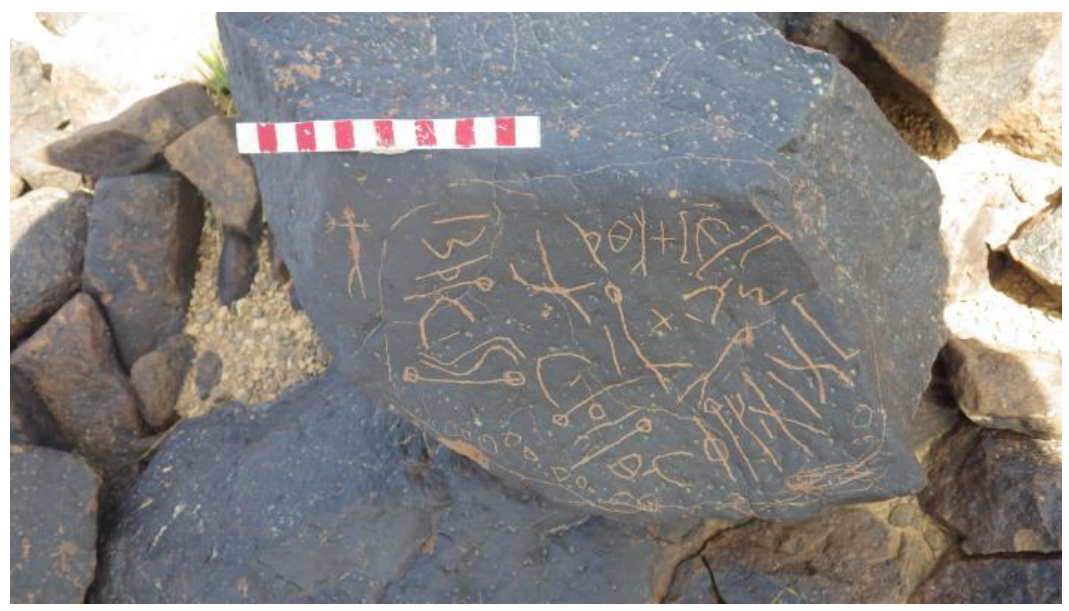

Figure 13. Stone 11 (Photograph: A. Al-Manaser) 


\section{BES_TH_19}

\section{Transliteration}

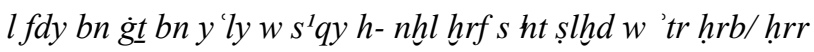

\section{Translation}

By Fdy son of Ġt son of Y'ly and he watered at this valley during the first rains the year Șlhd and 'tr waged war [?]

\section{Commentary}

This is the fifth Safaitic inscription (including the two written by authors who claim to be of the ' $l$ slhd) that refers to Salkhad (Damascus Museum 26750, KRS 301, 2813) which is located in southern Syria, $20 \mathrm{~km}$ to the east of Bosra. The author dates this inscription to the activity he performed in the year of Salkhad. This is a common way used by 'Safaitic' authors to date their inscriptions by using the term snt "year" (see OCIANA, s'nt) followed by an event that took place or a relatively important activity done by the author during that year. The author of this inscription indicates that he watered from the valley that is shown in Figure 14. The author wanted to highlight that he had watered his herd animals from this valley. It might be suggested that the author might have been on a visit to Salkhad, which was considered a center of worship for the deity Lat in the first century CE (Alpass 2011: 234-236). Alternatively, it could be suggested that the region was perhaps suffering a year of scarce rain (drought), and thus watering from this valley in that year was an important event to him. Regarding the word ' $t r$, it is difficult to find its precise meaning but it could be proposed that the author of the inscription had moved away from the war in the year he visited the town of Salkhad. Salkhad was known in the first century $\mathrm{CE}$ as a center for the worship of the deity Lat, where a temple was built for Lat. The stones of this temple were used later in the construction of some buildings in the present town. The presence of this temple can be inferred through the Nabataean inscription whose author indicates that he built the temple for the deity Lat. This inscription reads as follows:

\section{1. dnh byt' dy bnh rwhw br mlkw br 'klbw br rwhw l'lt 'lhthm \\ 2. dy b-ṣlhd wdy nșb rwhw br qșyw 'm rwhw dnh dy 'l' \\ 3. byrh ’b šnt ‘̌r wšb' lmlkw mlk nbțw br hrtt mlk nbțw rḥm \\ 4. 'mh}

"This is the temple which was built by $r w h w$, son of mlkw, son of 'klbw, son of $r w h w$, for Allat their goddess who is at Salkhad, and which was founded by $r w h w$, son of $q s y w$, great grandfather of this rwhw mentioned above. In the month of $\mathrm{Ab}$, in the seventeenth year of Malichus, king of the Nabataeans, son of Aretas, king of the Nabataeans, who loves his people" (Alpass 2011: 234). ${ }^{4}$

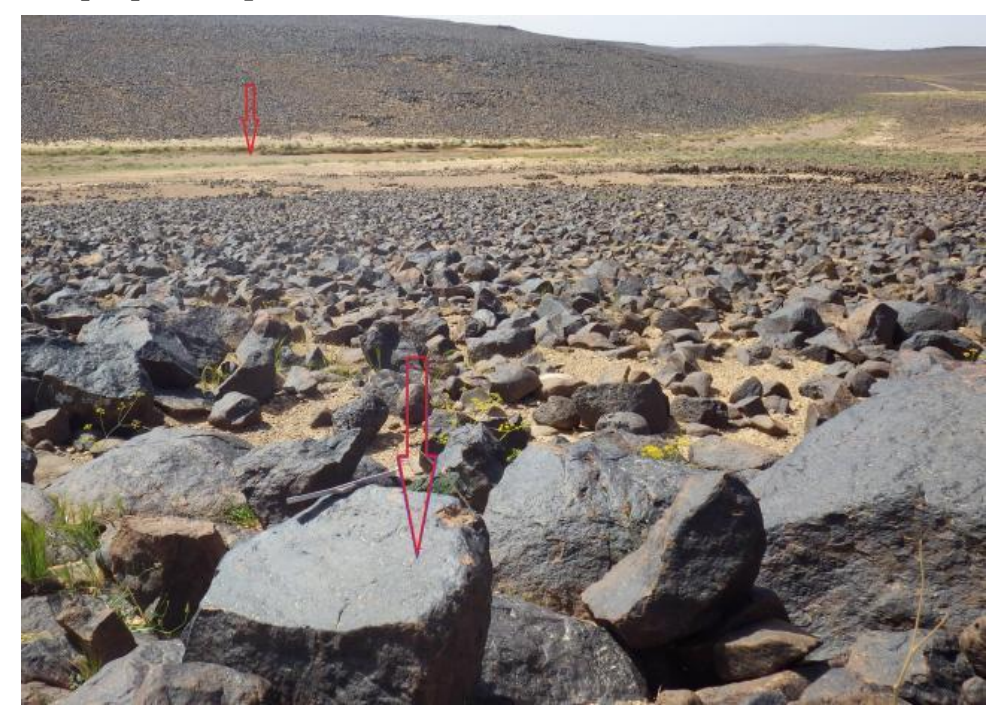

Figure 14. A photograph showing the sites where the inscriptions were recorded and showing the nearby valley (Photograph: A. Al-Manaser).

\footnotetext{
${ }^{4}$ CIS II 182; Cantineau 1932 p. 16-17 and see ; Macdonald 1993: 348-349.
} 
Knowing the location where the inscription was discovered and linking it directly with the interpretation of the inscription clearly contributes to a clearer understanding of the message or information that the inscription wanted to communicate to the one who will read the inscription after him. In Safaitic inscriptions, the authors tried to convey a specific picture to who will come after them about their emotions, the events they came across, the way of their life, the way they spend their time. Therefore, it is important for scholars who discover such inscriptions to report a complete picture of location of the inscription because the author might have wanted to deliver specific information through the place where he wrote his inscription.

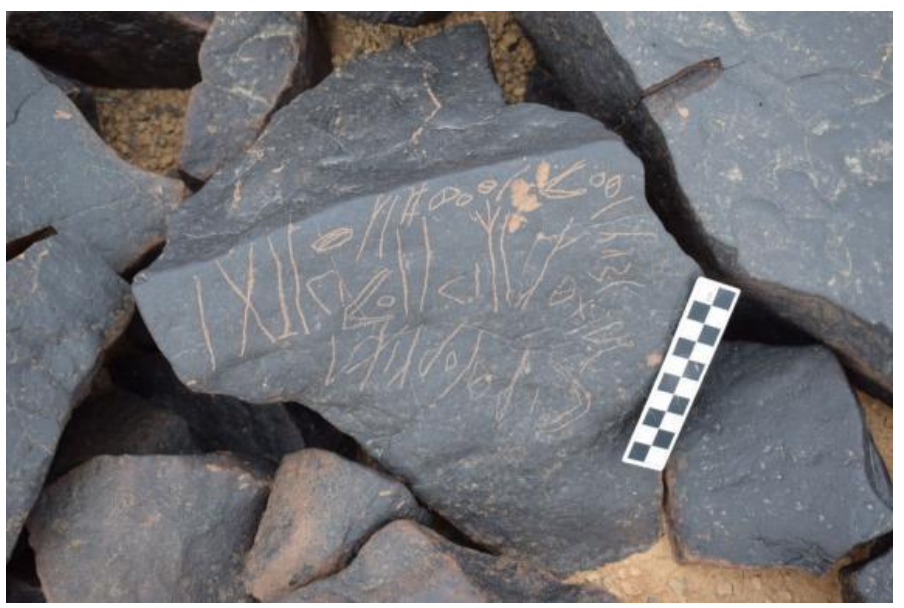

Figure 15. Stone 12 (Photograph: A. Al-Manaser).

\section{BES_TH_20}

\section{Transliteration}

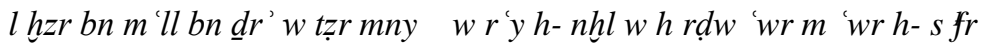

\section{Translation}

By Hzr son of M'll son of $\operatorname{Dr}^{\prime}$ and he awaited fate and he pastured the valley and O Rḍw [inflict] blindness/ harm on whoever scratches out the inscription

\section{Commentary}

The author of the inscription indicates that he pastured the valley, which appears in the Figure 16. The author tries to stress on the significance of the act he did by residing and grazing his herd animals in this valley. This inscription was discovered on one of the rocks of a cairn that overlooks the valley. It appears that the author wrote this inscription during grazing his animals in that valley.

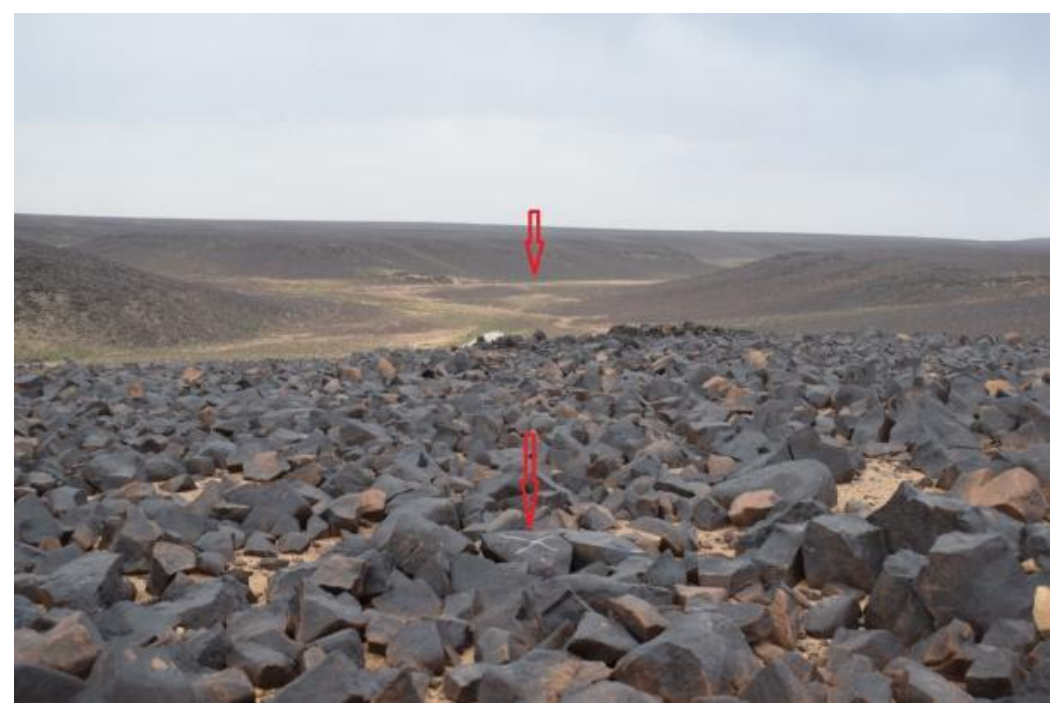

Figure 16. A photograph showing the sites where the inscriptions were recorded and showing the nearby valley (Photograph: A. Al-Manaser). 


\section{Discussion}

This research introduces a group of inscriptions through which it attempts to reinterpret the verb, ' $w r$, based on the sensual meaning rather than the literal meaning. This is based on the authors' belief that the accurate interpretation of this word, which is still commonly used among the inhabitants of the Badia in the Levant and the Gulf regions, in the religious context in Safaitic inscriptions is more likely to be the broad meaning of harm rather than the particular loss of one eye. It is clearly noticed from the afore-mentioned inscriptions and from the Safaitic inscriptions in general that the authors of Safaitic inscriptions used to request from their deities that, in order for their original inscriptions to be protected, for harm to be inflected upon those who choose to vandalize their inscriptions (Al-Manaser, 2008, p. 68). These requested harms are usually in the form of permanent and apparent physical disabilities or diseases that had no remedies at that time such as lameness, blindness, dumbness, and mange. However, the most commonly used request in this regard is the verb, 'wr. In fact, most examples of the use of the verb, 'wr, has since been translated by scholars and academicians to mean 'go blind!'. Additionally, it is also believed that this Safaitic verb is, in actuality, related to the Arabic verb, 'awar, which is known to translate to "to lose an eye, be or become one-eyed" (Lane 2193c).

This translation is believed by authors to be more consistent with what is meant by this word when used by the Bedouins in the Levant and the Gulf regions. For example, the Bedouins extensively use a derivative of the verb, 'wr, when they want to warn someone not to harm himself (see Lane 2193c 'āra-hu "he destroyed him"; 2194b 'awar "weakness,... disgrace, or disfigurement"). Interestingly, this verb is still widely and explicitly used in the Jordanian dialect. Furthermore, another translation of, ' $w r$, is often referenced as 'scratches out' (HCH 85; NST 3; AAEK 109). However, it is still not entirely clear to researchers, scholars and academicians particularly focused on this field of study, whether or not, 'wr, should be strictly taken and used as a verb or rather as a 'substantive term'. Nonetheless, the original meaning and significance of this term still remains intact when applied in a religious context, specifically with regards to prayer and worship. However, on the contrary, if one is to understand this term as a verb instead then, it could be the case that it exists as a 'precative imperative (' $w r \underline{d}$ $y^{\prime} w r$ : imperative / ' $w r l-\underline{d} y^{\prime} w r$ : substantive) as well (Al-Manaser, 2018, pp. 101-110).

It is important when interpreting the inscriptions to know the geographical location in which the inscription was found. This knowledge contributes to a clearer understanding of the meaning of the inscription and the message that the author of inscription wanted to convey to whoever reads the inscription later. In many cases, the geographical location carries an accurate explanation and a clearer picture of the information that the author wanted to communicate. For instance, the verb, nzrr/tzr r, appears to be most commonly found in inscriptions that are discovered in elevated areas, which are likely observation areas. It also appears that the author of such inscriptions wanted to convey a message that he waited at this elevated place for the purpose of observation. Likewise, the text " $w r^{c} y h-n h l$ " is often found near the course of a valley or an area that has water.

The substantial increase in the number of the so far discovered and documented Safaitic inscriptions during the last five years and the re-interpretation of a large number of previously published inscriptions- clearly indicate that the sensual interpretation of such scripts is far more accurate than the literal translation in this context (Macdonald \& Al-Manaser, 2015, p. 36; Macdonald \& Al-Manaser, 2019, p. 205).

\section{Acknowledgements}

The authors are greatly indebted to Michael C.A. Macdonald (University of Oxford) for his very helpful comments on an earlier draft of this paper. Special thanks are also due to the two anonymous reviewers for their valuable input and corrections. All errors remain our own.

\section{Editorial conventions}

\{ \} enclose letters and words of which the reading is doubtful

$\{/\}$ indicates alternative interpretations of the same letter

[ ] enclose letters or words which are restored

\section{Sigla}

AAEK

AbHYN

AbSWS

AMSI
Safaitic inscriptions in Al-Manaser 2008.

Safaitic inscriptions in Abbadi 1996.

Safaitic inscriptions in Abbadi 2006.

Inscriptions recorded by Ali Al-Manaser on the Wādī al-Ḥashād Survey in north-eastern Jordan in 2004 and published Ociana. 


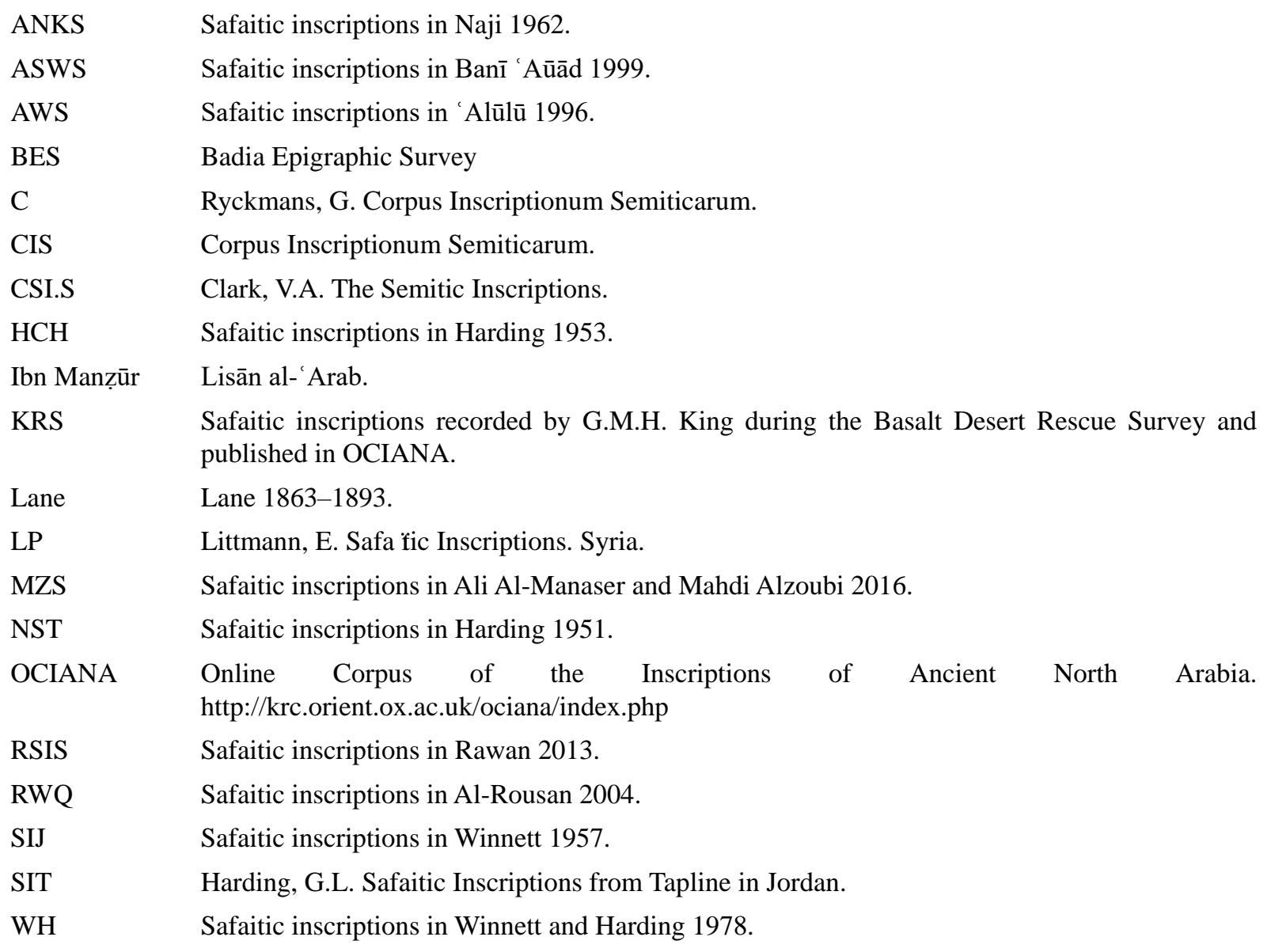

\section{References}

'Abbādī, S. (1996). Dikr ḥarb al-anbaţ wa-'1-yahūd fî 'l-nuqūš al-șafawiyyah. Mu'tah li-l-buhūt wa-'l-dirāsāt, al-'ulūm al-insāniyyah wa-'l-iğtimā 'iyyah [ğāmi 'at mu'tah], 11(2), 239-253.

'Abbādī, S. (2006). Nuqūšs șafawiyyah min wādī salmā (al-bādiyah al-urduniyah). Amman: Badia Research and Development Center.

Alpass, P. J. (2011). The Religious Life of Nabataea. Durham theses, Durham University. Available at Durham E-Theses Online: http://etheses.dur.ac.uk/3293/

Al-Jallad, A.M. (2014). An ancient Arabian zodiac. The constellations in the Safaitic inscriptions, Part I. Arabian Archaeology and Epigraphy, 25, 214-230.

Al-Manaser, A. (2008). Ein Korpus neuer safaitischer Inschriften aus Jordanien. Aachen, Shaker Verlag (Semitica et Semitohamitica Berolinensia / SSHB 10).

Al-Manaser, A. (2018). Understanding Safaitic inscriptions in their topographical context. In M. C. A. Macdonald (Ed.), The Proceedings of the Seminar for Arabian Studies (Vol. 48, pp. 101-110). Languages, scripts and their uses in ancient North Arabia.

Al-Manaser, A., \& Ellis, L. (2018). New Islamic inscriptions from the Jordanian Badia region. Arabian Epigraphic Notes, 4, 69-86.

Al-Manaser, A., \& Mahdi Alzoubi, M. (2016). New Epigraphical Material from Jordan. Palestine Exploration Quarterly, 148(1), 59-69.

Al-Rousan, M. M. (2004). Nuqūšs șafawīyah min wādī qișșāb bi-'l-urdun. Dirāsah maydānīyah taḥlīlīyah muqāranah. Unpublished doctoral thesis King Sa ūd University, Riyadh.

'Alūlū, Ġ. M. Y. (1996). Dirāsat nuqūus șafawìyyah jadīdah min wādī al-sū' ğanūb sūrīyyah. Unpublished M.A. thesis, Yarmouk University.

Ban̄̄ 'Aūād, 'Abdel ar-Raḥman. (1999). Dirāsat nuqū̌s șafawiyyah ğadīdah min ğanūb wādī sārah/ al-bādiyah 
al-'urdunniyyah aš-šamāliyyah. Unpublished MA thesis, Yarmouk University.

Cantineau, J. (1932). Le nabatéen. 2. Choix de textes, léxique. Paris.

Clark, V. A. (1987). The Semitic Inscriptions. Pages 723-755, pl. 95-109 in S.T. Parker (Ed.), The Roman Frontier in Central Jordan. Interim Report on the Limes Arabicus Project, 1980-1985. (British Archaeological Reports, International Series, 340.2). Oxford: BAR.

Harding, G. L. (1951). New Safaitic Texts. Annual of the Department of Antiquities of Jordan, 1, 5-29.

Harding, G. L. (1953). The Cairn of Hani' . Annual of the Department of Antiquities of Jordan, 2, 8-56.

Harding, G. L. (1972). Safaitic Inscriptions from Tapline in Jordan. Annual of the Department of Antiquities of Jordan, 17, 5-14 and 2 unnumbered plates.

Ibn Manzūr, Muhammad b. al-Mukarram. (1981). Lisān al- 'Arab. Țab'ah ğadīdah muhaqqaqah wa-maškūlah šaklan kāmilan wa-muḍayyalah bi-fahāris mufașșalah. (7 volumes). Al-Qāhirah: Dār al-Ma'ārif, n.d. (3rd edition) [1st ed. 1981].

Lane, E. W. (1863-1893). An Arabic-English Lexicon, Derived from the Best and Most Copious Eastern Sources. London: Williams and Norgate.

Littmann, E. (1943). Safaitic Inscriptions, Syria. Leiden, Brill (Publications of the Princeton University Archaeological Expeditions to Syria in 1904-1905 and 1909. Division IV, Section C).

Macdonald, M. C. A. (1993). Nomads and the Hawrān in the late Hellenistic and Roman periods: A reassessment of the epigraphic evidence. Syria, 70, 303-413. [Reprinted with the same pagination, plus addenda and corrigenda as Article II in M.C.A. Macdonald, Literacy and Identity in Pre-Islamic Arabia, (Variorum Collected Studies Series no. 906), Farnham: Ashgate, 2009].

Macdonald, M., \& Al-Manaser, A. (2019). Recording Graffiti in the Black Desert: Past, Present, and Future. Journal of Eastern Mediterranean Archaeology and Heritage Studies, 7(2), 205-222.

Macdonald, M., \& Al-Manaser, A. (2019). Report on the Wādī Salma Area Epigraphic Survey, April 2015. Bulletin for the Council for British Research in the Levant, 21(1), 36-39.

Musil, A. (1928). The Manners and Customs of the Rwala Bedouins (Oriental Explorations and Studies, 6). New York: American Geographical Society.

Naji, A. (1962). Kitābah ṣafawiyyah min șahrāā al-ruṭbah. Sumer, 18, 165-170, pl. 1 [Arabic section].

Rawan, S. (2013). Neue safaitische Inschriften aus Süd-Syrien. (Semitica et Semitohamitica Berolinensia / SSHB 16). Aachen: Shaker.

Ryckmans, G. (Ed.) (1951). Corpus Inscriptionum Semiticarum: Pars Quinta, Inscriptiones Saracenicae Continens: Tomus I, Fasciculus I, Inscriptiones Safaiticae. Paris, Imprimerie nationale.

Winnett, F. V. (1957). Safaitic Inscriptions from Jordan. Toronto, University of Toronto Press (Near and Middle East Series 2).

Winnett, F. V., \& Harding, G. L. (1978) Inscriptions from Fifty Safaitic Cairns. Toronto, University of Toronto Press (Near and Middle East Series 9).

\section{Copyrights}

Copyright for this article is retained by the author(s), with first publication rights granted to the journal.

This is an open-access article distributed under the terms and conditions of the Creative Commons Attribution license (http://creativecommons.org/licenses/by/4.0/). 